\title{
Reduction in preterm births during the COVID-19 lockdown in Ireland: a natural experiment allowing analysis of data from the prior two decades.
}

\author{
Philip $\mathrm{RK}^{1,2^{*}}$, Purtill $\mathrm{H}^{3}$, Reidy $\mathrm{E}^{4}$, Daly $\mathrm{M}^{5}$, Imcha $\mathrm{M}^{6}$, McGrath $\mathrm{D}^{2}$, \\ O'Connell $\mathrm{NH}^{2,7}$, Dunne $\mathrm{CP}^{2}$
}

${ }^{1}$ Division of Neonatology, Department of Paediatrics, University Maternity Hospital Limerick (UMHL), Limerick, V94 C566, Ireland. ${ }^{2}$ School of Medicine and Centre for Interventions in Infection, Inflammation, and Immunity (4i), University of Limerick, Ireland. ${ }^{3}$ Department of Mathematics and Statistics, University of Limerick, Limerick, Ireland. $\quad{ }^{4}$ Midwifery and Neonatal Nursing, University Maternity Hospital Limerick (UMHL), Ireland. ${ }^{5}$ Advocacy and Policymaking, Irish Neonatal Health Alliance (INHA), Bray, Wicklow, Ireland. ${ }^{6}$ Department of Obstetrics and Gynaecology, University Maternity Hospital (UMHL), Limerick, Ireland. ${ }^{7}$ Department of Clinical Microbiology, University Hospital Limerick (UHL), Ireland.

${ }^{\star}$ Corresponding Author: Prof. Roy K Philip, Adjunct Professor of Neonatology, University Maternity Hospital Limerick (UMHL) and School of Medicine, University of Limerick, Limerick, V94 C566, Ireland. Tel: +353872209717 Email: roy.philip@hse.ie

ORCID: https://orcid.org/0000-0002-6097-9869

\section{Abstract}

Background: Aetiology of preterm birth (PTB) is heterogeneous and preventive strategies remain elusive. Socio-environmental measures implemented as Ireland's prudent response to the SARS-CoV-2 virus (COVID-19) pandemic represented, in NOTE: This preprint reports new research that has not been certified by peer review and should not be used to guide clinical practice. 
medRxiv preprint doi: https://doi.org/10.1101/2020.06.03.20121442; this version posted June 5, 2020. The copyright holder for this preprint (which was not certified by peer review) is the author/funder, who has granted medRxiv a license to display the preprint in perpetuity.

All rights reserved. No reuse allowed without permission.

effect, a national lockdown and have possibly influenced the health and wellbeing of pregnant women and unborn infants. Cumulative impact of such socio-environmental factors operating contemporaneously on PTB has never been assessed before.

Methods: Regional PTB trends of very low birth weight (VLBW) infants in one designated health area of Ireland over two decades were analysed. Poisson regression and rate ratio analyses with $95 \% \mathrm{Cl}$ were conducted. Observed regional data from January - April 2020 were compared to historical regional and national data and forecasted national figures for 2020.

Results: Poisson regression analysis found that the regional historical VLBW rate per 1000 live births for January to April, $2001-2019$ was 8.18 (95\% Cl: $7.21,9.29)$. During January to April 2020, an unusually low VLBW rate of just 2.17 per 1000 live births was observed. The rate ratio of $3.77(95 \% \mathrm{Cl}: 1.21,11.75), \mathrm{p}=0.022$, estimates that for the last two decades there was, on average, 3.77 times the rate of VLBW, compared to the period January to April 2020 during which there is a $73 \%$ reduction. National Irish VLBW rate for 2020 is forecasted to be reduced to 400 per 60,000 births compared to the historical $500-600$ range.

Conclusion: An unprecedented reduction in PTB of VLBW infants was observed in one health region of Ireland during the COVID-19 lockdown. Potential determinants of this unique temporal trend reside in the summative socio-environmental impact of the COVID-19 dictated lockdown. Our findings, if mirrored in other regions that have adopted similar measures to combat the pandemic, demonstrate the potential to evaluate these implicated interdependent behavioural and socio-environmental modifiers to positively influence PTB rates globally.

Abstract word count: 300 (Limit 300) 


\section{Key Questions}

\section{What is already known?}

- Premature birth is an important contributor for under-five mortality globally.

- Currently there is no broadly accepted and effective strategy to prevent the birth of premature very low birth weight infants.

- Impact of socio-environmental and maternal behavioural modifications on the incidence of preterm birth has not been assessed.

\section{What are the new findings?}

- COVID-19-triggered national lockdown in Ireland created an opportunity to study the cumulative influence of socio-environmental modifications on pregnant mothers.

- An unprecedented $73 \%$ reduction in the rate of very low birth weight deliveries was noted in one designated health region of Ireland during January to April of 2020 in comparison to the preceding 20 year timeframe.

- Our observations, if nationally mirrored, indicate that birth rate of very low birth weight premature infants in Ireland is forecasted to decrease considerably in 2020 .

\section{What do the new findings imply?}

- Socially rooted modifiers such as family support, work related stress and commuting, environmental pollution, infection avoidance, sleep and nutritional support, adequate exercise, reduced exposure to tobacco and illicit drugs, 
medRxiv preprint doi: https://doi.org/10.1101/2020.06.03.20121442; this version posted June 5, 2020. The copyright holder for this preprint (which was not certified by peer review) is the author/funder, who has granted medRxiv a license to display the preprint in perpetuity.

All rights reserved. No reuse allowed without permission.

avoidance of financial strain, all cumulatively could contribute to reduce preterm birth rate.

- Our observations, if reflected in other countries that adopted COVID-19prompted lockdown measures, would redefine the antecedents that trigger the yet poorly understood pathways leading to preterm births.

- Prematurity rate would be the most important 'curve to bend' in the context of reducing infant mortality globally and thus promote the achievement of sustainable development goals for children.

Key words: prematurity; very low birth weight (VLBW); extremely low birth weight (ELBW); preterm birth; COVID-19; lockdown; socio-environmental modifiers; NICU; sustainable development goals (SDGs); global health

\section{Introduction}

Over 15 million babies are born too early, too sick and too small in the world every year. One million of these infants die. ${ }^{1}$ Preterm birth (PTB), below 37 weeks of gestation, contributes significantly to infant mortality. ${ }^{2,3,4,5}$ In $2016,46 \%$ of the underfive mortality globally was contributed to by neonatal deaths within the first 28 days of life and the main contributor was prematurity. ${ }^{5}$ PTB rate is increasing in most developed and developing countries and a significant proportion of spontaneous PTB is of unknown aetiology. ${ }^{2,6}$ The frequency of PTB varies from $5-9 \%$ in Europe, $10.6 \%$ in North America to $11.9 \%$ in Africa. ${ }^{7,8}$ While repeated PTB is reported, most 
medRxiv preprint doi: https://doi.org/10.1101/2020.06.03.20121442; this version posted June 5, 2020. The copyright holder for this preprint (which was not certified by peer review) is the author/funder, who has granted medRxiv a license to display the preprint in perpetuity.

preterm very low birth weight (VLBW, <1,500 gm) and extremely low birth weight (ELBW, $<1,000 \mathrm{gm}$ ) infants are born to women with no prior history of PTB. ${ }^{5,9}$

Prevention of PTB is considered a public health priority. Despite the obvious and growing relevance, progress has been modest. ${ }^{10}$ Currently there is no standardised and effective strategy to prevent PTB, and implementation of socio-cultural approaches to mitigate the risk of PTB would require better elucidation of nonmedical factors that are both under-recognised and under-evaluated. ${ }^{11}$ Although the causal biological mechanisms mediating PTB are poorly understood, preterm premature rupture of membranes (PPROM) complicates one third of all PTB. ${ }^{12}$ Suggested alternate biological antecedents include amnionic inflammasome, alterations to vaginal microbiota, variations in cytokines, chemokines and other inflammatory modulators, as well as intra-amniotic inflammation (IAI) and infections. $^{13,14,15}$ It has been suggested that socio-environmental phenotype could offer insights and recognising the sources of heterogeneity and phenotypic plasticity in PTB may inform eventual effectiveness of preventive measures. ${ }^{16,17}$

Ireland offers a unique opportunity to evaluate PTB as it has been one of the very few developed countries that legally prohibited termination of pregnancy (TOP) or abortion until the 'Regulation of Termination of Pregnancy Act' was passed on $20^{\text {th }}$ December 2018 with services initiated on $1^{\text {st }}$ January $2019 .{ }^{18}$ In that specific setting, there existed an opportunity to compare data from the pre-TOP era with 2020 data to determine the potential influence on PTB rates due to socio-environmental measures implemented as Ireland's prudent response to the SARS-CoV-2 virus (COVID-19) pandemic. In effect, these measures constituted a national lockdown and may possibly have influenced the health and wellbeing of pregnant women and their 
medRxiv preprint doi: https://doi.org/10.1101/2020.06.03.20121442; this version posted June 5, 2020. The copyright holder for this preprint (which was not certified by peer review) is the author/funder, who has granted medRxiv a license to display the preprint in perpetuity.

All rights reserved. No reuse allowed without permission.

unborn infants. We wished to assess these redefined social and behavioural boundaries that could foster an environment encompassing elements that are favourable to pregnancies reaching full term.

\section{Methods}

\section{Setting}

A nationwide lockdown was adopted in Ireland on $12^{\text {th }}$ March 2020 in response to the COVID-19 pandemic and was extended to $18^{\text {th }}$ of May with the shutdown of offices, shops, colleges, schools, childcare facilities and all other institutions deemed non-essential. Traffic and mobility restrictions were imposed and most of the workforce had to adapt to a new work-from-home (WFH) model. Department of Health, National Public Health Emergency Team (NPHET) and Health Service Executive (HSE) of Ireland were advising the population from mid-February 2020 to follow strict hand hygiene measures, social distancing and adherence to WHO recommendations to reduce COVID-19 transmission. This period of national lockdown and the pre-lockdown weeks of extra healthcare vigilance and restrictions resulted in holistic alterations to the wellbeing of pregnant women. Potential influence of a multitude of biological, physical and environmental factors could cumulatively influence and modify the PTB of VLBW infants. These few months offered a unique opportunity to study the effects of a 'Nature's experiment' of nonmedical, behavioural and socio-environmental alterations as the key determinants restoring overall health of the 'intrauterine habitat' and influencing the continuation of foetal life.

\section{Study population}


medRxiv preprint doi: https://doi.org/10.1101/2020.06.03.20121442; this version posted June 5, 2020. The copyright holder for this preprint (which was not certified by peer review) is the author/funder, who has granted medRxiv a license to display the preprint in perpetuity.

All rights reserved. No reuse allowed without permission.

University Maternity Hospital Limerick (UMHL), serving as the only maternity facility to a population of 473,000 from the counties of Limerick, Clare, North Tipperary and nearby catchment areas provides a unique opportunity to analyse the demographic and epidemiologic trends of births involving VLBW and ELBW infants of one of the designated health regions in the Republic of Ireland. ${ }^{19}$ All preterm infants from 22 weeks of gestation are treated locally (apart from surgical or cardiac interventions) and our perinatal demography and patient characteristics of the very preterm population have already been published. ${ }^{20}$ PTB involving VLBW infants from 22 weeks of gestation onwards at UMHL from $1^{\text {st }}$ January 2001 to $30^{\text {th }}$ April 2020 were included in the study. Retrospective descriptive datasets were linked from the labour ward register, neonatal admission register and pre-submission data towards the Vermont Oxford Network (VON) international benchmarking. ${ }^{21}$ No cases were excluded based on congenital anomalies, multiple gestations or inconsistencies around gestational age estimation. We did not sub-classify PTB to spontaneous onset of labour with intact membranes, PPROM or medically initiated labour onset through induction or caesarean. ${ }^{7}$ Our VLBW trends were compared with the published National figures from Central Statistics Office (CSO) and the National Perinatal Epidemiology Centre (NPEC) of Ireland. ${ }^{22,23}$

\section{Hypothesis}

There were no overarching significant alterations to the antenatal, obstetric or intrapartum care pathways initiated for the pregnant women at UMHL or our health region from January-April of 2020 compared to preceding years. This offered us the opportunity to hypothesise whether the non-medical, community-based, socioenvironmental determinants and modifiable behavioural factors brought on by the 
medRxiv preprint doi: https://doi.org/10.1101/2020.06.03.20121442; this version posted June 5, 2020. The copyright holder for this preprint (which was not certified by peer review) is the author/funder, who has granted medRxiv a license to display the preprint in perpetuity.

All rights reserved. No reuse allowed without permission.

Irish public health responses to COVID-19 pandemic and lockdown would be of significance to our observed temporal trends in PTB rates.

\section{Statistical analysis}

Fully anonymised and de-identified dataset fulfilling general data protection regulation (GDPR) compliance was prepared for statistical analysis. ${ }^{24}$ Significance of temporal trends in the VLBW and ELBW rates per 1000 births were assessed using Poisson regression, where time was entered as a continuous variable. Poisson regression with $95 \%$ Wald confidence intervals and rate ratio analysis were used to compare the observed VLBW rate for Jan-April of 2020 at UMHL to historical data. Estimates of the prevalence of VLBW and ELBW per 1000 births pre-2020 assessed the potential impact of January - April 2020 regional data on the national expectation of VLBW for 2020 in Ireland (based on the previous published Irish data from VON and CSO). ${ }^{21,22,23}$ All data were analysed using IBM SPSS Statistics V.26.

\section{Patient and Public Involvement}

Patient and public involvement (PPI) was initiated at the outset of research planning. Irish Neonatal Health Alliance (INHA), the patient advocacy group (Registered Charity Number: 20100100) representing parents of newborn infants in Ireland and member of European Foundation for the Care of Newborn Infants (EFCNI), was invited at the design stage of the study and was a signatory in the Research Ethics submission. INHA reviewed the aims of the study and confirmed that the issues addressed through the research is of relevance to patients and public. INHA reaffirmed that the patient confidentiality is not breached at any stage of the research, and specifically requested forecasting of National VLBW births through appropriate analysis in order for the advocacy group to prioritise their family centred 
medRxiv preprint doi: https://doi.org/10.1101/2020.06.03.20121442; this version posted June 5, 2020. The copyright holder for this preprint (which was not certified by peer review) is the author/funder, who has granted medRxiv a license to display the preprint in perpetuity.

All rights reserved. No reuse allowed without permission.

care programmes for 2020. INHA also nominated a parent of a premature VLBW infant to be an independent external reviewer of VLBW and ELBW data for 2020. Designated representative of the patient advocacy group is a member of the study team and authorship of the manuscript. Once published, the relevant findings of the study will be disseminated through the websites of INHA www.inha.ie and EFCNI www.efcni.org Guidance for Reporting Involvement of Patients and the Public (GRIPP2) reporting checklist as applicable to this study has been fulfilled. (Appendix 1)

\section{Data verification and Reporting}

Considering the unprecedented and significant reduction of the VLBW and ELBW numbers observed during the lockdown and pre-lockdown phases of extra public health vigilance, we have verified the accuracy and authenticity of primary data capture with external independent professionals and patient representative (as part of the PPI initiative) who are not members of the research team or authorship.

\section{Ethics Approval}

University Hospital Limerick Research Ethics Committee approval was granted for the study.

\section{Results}

Over the last twenty years UMHL had 93,018 live births and during the four months of January to April from 2001 to 2020 there were 30,705 live births. Annual live births, annual ELBW and VLBW rates as well as the respective numbers for $1^{\text {st }}$ January to $30^{\text {th }}$ April of each year for the last two decades are summarised in Table 1. Poisson regression analyses of the $2001-2019$ data did not find any evidence of 
medRxiv preprint doi: https://doi.org/10.1101/2020.06.03.20121442; this version posted June 5, 2020. The copyright holder for this preprint (which was not certified by peer review) is the author/funder, who has granted medRxiv a license to display the preprint in perpetuity.

temporal trends for UMHL January - April VLBW (Wald Chi-square $=0.784, p=$ 0.376), January - April ELBW (Wald Chi-square $=0.464, p=0.496$ ), annual VLBW (Wald Chi-square $=0.366, p=0.545)$ or annual ELBW (Wald Chi-square $=0.008, p$ $=0.929)$.

The VLBW rate per 1000 live births (January - April) based on aggregate 2001 2019 data was 8.18 (95\% Wald Cl: 7.21, 9.29), representing a forecast January April 2020, in the absence of a temporal trend. However, the observed total number of only three VLBW in January - April 2020 (all of them born before mid-February 2020, with no ELBW) confirms an unusually low VLBW rate of just 2.17 per 1000 live births (95\% Wald Cl: $0.70,6.74), 73 \%$ lower than the forecasted rate of 8.18 . (Figure 1). The Rate Ratio comparing the risk of VLBW in January - April 2001-2019 to that from January - April in 2020 was 3.77 (95\% Wald Cl: 1.21, 11.75), $p=0.022$, suggesting that for two decades pre-2020 there was 3.77 times the rate of VLBW for the months of January - April in comparison to 2020. The ELBW rate per 1000 live births for January - April using aggregated data from 2001 - 2019 was 3.0 (95\% Wald Cl: $2.43,3.70)$. There were no ELBW live births recorded for the health region during January - April 2020. (Figure 2)

The VLBW rate per 1000 live births from the aggregated regional numbers for 20012019 yearly data was computed to be 8.41 (95\% Wald Cl: 7.83, 9.04), providing a forecasted annual rate for 2020 . A continuation of the $73 \%$ reduction from forecast in the January-April VLBW rate for the health region for the remainder of 2020 would forecast a rate of 2.27 VLBW per 1000 live births. However, a reversal to the regional population's pre-lockdown behavioural and socio-environmental status quo could increase the rate towards the historical rates. 
medRxiv preprint doi: https://doi.org/10.1101/2020.06.03.20121442; this version posted June 5, 2020. The copyright holder for this preprint (which was not certified by peer review) is the author/funder, who has granted medRxiv a license to display the preprint in perpetuity.

All rights reserved. No reuse allowed without permission.

The forecast for the 2020 national VLBW rate is taken from the $2014-2017$ VON date for Ireland, giving a mean of 9.37 per 1000 live births, no trend is evident. (Table 3) If the national VLBW rate reflects the observed regional rate of $2.17(95 \%$ Wald $\mathrm{Cl}$ : $0.70,6.74)$ (January-April 2020), the upper confidence limit estimates the number of VLBW infants to be born in Ireland in 2020 could be reduced to approximately 400 per 60,000 births (historically 500-600). (Table 2) However, variation in the population's compliance with lockdown in other regions of the country and postlockdown deterioration in behavioural and socio-environmental factors or the possibility of a 'baby boom' in late 2020 could regain the PTB rate back to the historical over 500 per 60,000 births.

\section{Discussion}

Prematurity poses significant medical, emotional, physical, psychological and financial burden for the affected infants, their support network, health systems, economies and society as a whole. ${ }^{25}$ PTB through significant neonatal morbidity also leads to long-term health concerns during childhood. ${ }^{26}$ A myriad of etiologic and antecedent factors could trigger PTB and the effectiveness of preventive measures depends on our precise understanding of the causation. ${ }^{10} \mathrm{~A}$ pan-European study found rising PTB rates in most countries and an increase in multiple births as well as assisted reproduction techniques (ART) also contributed to the overall increase. Understanding cross-country differences also could inform strategies for PTB reduction. $^{27}$

Pregnancy is an ideal opportunity to encourage positive behavioural changes. ${ }^{28}$ Pregnancy Risk Assessment Monitoring System (PRAMS) in Ireland, National Institute of Clinical Evidence (NICE) guidelines as well as the 'Safer Maternity Care' 
medRxiv preprint doi: https://doi.org/10.1101/2020.06.03.20121442; this version posted June 5, 2020. The copyright holder for this preprint (which was not certified by peer review) is the author/funder, who has granted medRxiv a license to display the preprint in perpetuity.

document in UK are worthy initiatives aimed at PTB reduction. ${ }^{28,29,30}$ However, the yet under-recognised, behavioural, socio-cultural and socio-environmental modifications and opportunities designed to prolong the intrauterine nurturing milieu could offer far more to reduce PTB rates.

Prenatal period and foetal growth could be regarded as a matrix for our lives and societies. ${ }^{31}$ PTB also could have an evolutionary basis of predictive adaptive response congruous with the Developmental Origins of Health and Disease $(\mathrm{DOHaD}) .^{32,33}$ Heterogeneous origins of PTB rate could be influenced by environmental changes, modifiable population factors, nutritional variations, stress factors and socioeconomic status. ${ }^{17,33}$

\section{Potential influence of the termination of pregnancy and stillbirths}

As one of the very few developed regions of the world with abortion legally banned till late 2018, Ireland offers a unique opportunity to evaluate the natural history of PTB and the wider relation to socio-environmental alterations. Could the very low ELBW and VLBW figures in early 2020 be explained partially by the change in TOP law, allowing for TOP beyond 12 weeks gestation in the presence of major congenital anomalies (MCA) that limits foetal or neonatal viability? Examination of our regional and national historical data suggest not.

Historical mean prevalence of MCA among our regional cohort of VLBW from 2000 to 2018 (two decades of no TOP) was a mean of $9.2 \%$ and the national mean for 2014, 2015, 2016 and 2017 were 9\%, 7\%, 9\% and 8\% respectively (55/596, 42/622, 54/593 and 51/612). ${ }^{23}$ That is, less than 1 in every $10 \mathrm{VLBW}$ had the presence of MCA when no TOP was available. The TOPs undertaken in 2019 and 2020 from January- April (two in 2019 and four in 2020) beyond 12 weeks of gestation were for 
medRxiv preprint doi: https://doi.org/10.1101/2020.06.03.20121442; this version posted June 5, 2020. The copyright holder for this preprint (which was not certified by peer review) is the author/funder, who has granted medRxiv a license to display the preprint in perpetuity.

All rights reserved. No reuse allowed without permission.

MCA in our region, in accordance with the national guidelines on compassionate grounds. ${ }^{18}$ There was no increasing trend for the stillbirth rate (SBR) of UMHL or the region during the study period, confirming no 'displacement of vital statistics' as an explanation for the VLBW reduction.

\section{COVID-19 lockdown triggered socio-environmental and behavioural modifiers.}

The 'Nature's experiment' through the COVID-19 lockdown triggered unparalleled and widespread socio-environmental alterations which we hypothesise as the plausible explanation for PTB of VLBW rate to fall from $8.18(95 \% \mathrm{Cl}: 7.21,9.29)$ to $2.17(95 \% \mathrm{Cl}: 0.70,6.74)$ per 1000 live births for the January - April period. Specific modifiers, both facilitators and barriers, in the socio-cultural and socio-environmental settings that in our view would have influenced the mother-foetus pair to reduce the chances for PTB during the COVID-19 lockdown and pre-lockdown weeks of enhanced public health vigilance are summarised below (Figure 3).

\section{Pregnancy associated stress, anxiety and support systems}

Psychological stresses increase the likelihood of PTB. Positive benefits from familial support have been reported. ${ }^{9}$ Male partner involvement on reducing PTB rates has been suggested. ${ }^{34}$ Compared to women who reported no partner involvement and support during pregnancy, those who had it reported better psychological wellbeing. ${ }^{35}$ There is strong evidence that pregnancy-specific anxiety, depression and stress increase the likelihood PTB ${ }^{36}$ Impacts of on-call work during pregnancy in relation to stress and sleep are not well established. ${ }^{37}$ Measures of psychological distress including alterations in blood corticotrophin-releasing hormone $(\mathrm{CRH})$ levels and cortisol are associated with PTB. ${ }^{38}$ The biologic pathways underlying stressinduced PTB remain poorly understood. ${ }^{39}$ We postulate therefore that the reduced 
medRxiv preprint doi: https://doi.org/10.1101/2020.06.03.20121442; this version posted June 5, 2020. The copyright holder for this preprint (which was not certified by peer review) is the author/funder, who has granted medRxiv a license to display the preprint in perpetuity.

All rights reserved. No reuse allowed without permission.

pregnancy associated stress and increased support systems available during the COVID-19 lockdown could be contributory factors in the low levels for PTB of VLBW seen in the region.

\section{Work related stress, physical work, shift work and on-calls}

Studies suggest an association of shift work, fixed night shifts and long working hours during pregnancy with PTB. ${ }^{40,41}$ Women working more than 55.5 hours (vs 40 hours) per week had a $10 \%$ increase in the odds of having a PTB. ${ }^{40}$ Danish National birth cohort study associated shift work with an increase in small-for-gestational-age (SGA). ${ }^{42}$

Physically demanding work while pregnant increases PTB as per systematic review and meta-analysis. ${ }^{40,43}$ A threefold increase in PTB was reported in women whose daily work entailed trunk bending for over one hour. ${ }^{44}$ Bed rest in hospital or at home is widely recommended as a conventional practice to prevent PTB through the possible reduction of uterine activity. While sufficient rest and relaxation seems appropriate, Cochrane review concluded neither supporting nor refuting the use of prolonged bed rest at home or in hospital, to prevent PTB. ${ }^{45}$ It is possible that the change in work practices due to the COVID-19 lockdown had the added benefit of reducing prematurity.

\section{Environmental factors, temporal variations, air pollution}

A Unites States study exploring temporal patterns of PTB observed a periodicity for PTB rates. $^{46}$ Association between ambient air pollution (AAP) exposure during pregnancy and PTB has been reported. ${ }^{26,47,48}$ Particulate matter, nitrogen dioxide, ozone, and carbon monoxide were the most commonly used markers of AAP. ${ }^{47,48}$ 
medRxiv preprint doi: https://doi.org/10.1101/2020.06.03.20121442; this version posted June 5, 2020. The copyright holder for this preprint (which was not certified by peer review) is the author/funder, who has granted medRxiv a license to display the preprint in perpetuity.

All rights reserved. No reuse allowed without permission.

Sulphur dioxide $\left(\mathrm{SO}_{2}\right)$ was the largest contributor to increase PTB and other agents were particulate matter $(\mathrm{PM})_{2.5 \text { micron, }} \mathrm{PM}_{10}$ micron and $\mathrm{NO}_{2}{ }^{26}$ One study from Wuhan, China linked PTB to the atmospheric pollutant, vanadium. ${ }^{49}$ The relationship between atmospheric temperature and seasonal fluctuations to PTB has been suggested. ${ }^{50}$ European pattern is discerned with a spring peak and in Asia and US a seasonal variance of up to $5-10 \%$ has been reported. ${ }^{50}$

No major meteorological events were reported in Ireland during the 2020 lockdown in comparison to the preceding two decades and the observed decline in our VLBW rate is well beyond the variations in the natural annual temporal trends reported to date. Cumulative contribution to AAP improvement by a reduction in all modes of transport, reduced consumption of diesel and petrol, reduced production and distribution of goods and closure of factories, all led to reduced environmental pollution in UK and Europe during the lockdown. ${ }^{51}$

\section{Socioeconomic factors and financial strain}

'Growing up in Ireland survey' calculated the index for LBW arising from PTB and intrauterine growth restriction (IUGR) and an association with parental education and environmental conditions was observed. ${ }^{52}$ The UK Bradford study found that a new variable of interest, financial strain, was associated with a significant increase in PTB. ${ }^{53}$ Direct and timely financial assistance offered by the Irish Government during the lockdown to businesses, self-employed and employees who were temporarily laid off, possibly avoided financial strain on the pregnant families.

\section{Maternal nutrition, opportunities for wellbeing and exercise}


medRxiv preprint doi: https://doi.org/10.1101/2020.06.03.20121442; this version posted June 5, 2020. The copyright holder for this preprint (which was not certified by peer review) is the author/funder, who has granted medRxiv a license to display the preprint in perpetuity.

All rights reserved. No reuse allowed without permission.

Observational data suggest the influence of maternal under nutrition in spontaneous PTB, which support a role for optimal maternal pre-pregnancy and in-pregnancy nutritional status in determining gestational length. ${ }^{6} \mathrm{~A}$ low maternal body-mass index (BMI) was associated with spontaneous PTB. ${ }^{7}$ Compared to no exercise during pregnancy, those taking appropriate leisurely exercise lowered the risk of PTB and placental weight gain could partially mediate the association between exercise during pregnancy and PTB. ${ }^{54}$ Irish lockdown allowed for outdoor exercise within a two kilometre radius of home and Government initiatives promoted online wellbeing and exercise choices through the 'Healthy Ireland' platform. ${ }^{55}$

\section{Reduction of chances for infections during pregnancy}

Susceptibility to infectious diseases is often modified during pregnancy. Alterations in immunity to allow for the foetal allograft to implant and thrive combined with the anatomical and physiological modifications underlie these susceptibilities. ${ }^{56}$ It has been shown that relationship satisfaction reduces infectious diseases in pregnancy. ${ }^{57}$ Behavioural changes promoted during and prior to the lockdown, including social distancing, enhanced hand hygiene and use of face masks potentially reduced the chances of common viral infections during pregnancy. In addition, the closure of crèche, day-care centres, child minding facilities and play schools that normally 'bring home' common infections further reduced the potential for infective agent exposure. ${ }^{58}$ Adoption of WFH policies by pregnant women and their partners may have further reduced exposure to the 'microbial world' of the adult population. Consequently, there may have been a reduction in the likelihood of Influenza, parvovirus B19 and congenital cytomegalovirus (CMV) that are more significant infections during pregnancy, with acknowledged associations with PTB. ${ }^{58,59,60,61}$ 
medRxiv preprint doi: https://doi.org/10.1101/2020.06.03.20121442; this version posted June 5, 2020. The copyright holder for this preprint (which was not certified by peer review) is the author/funder, who has granted medRxiv a license to display the preprint in perpetuity.

\section{Daily commuting and road traffic incidents}

Irish national lockdown has brought down overall vehicular traffic, reduced the commuting to and from work locations, avoided early start and late return to home, attenuated traffic-related stresses and improved atmospheric air pollution. Arguably, the potential for crashes involving pregnant women should be low as well. After a single crash, pregnant drivers had increased rates of PPROM and PTB. ${ }^{62,63}$ Evaluation of potential adverse foetal outcome using a 26 weeks pregnant woman manikin has previously demonstrated significant harm using common accident scenarios. ${ }^{64}$ An observational study reported increased PTB following air travel, however large multi-centric studies would be warranted before drawing conclusions and the contribution to our study cohort would be low based on population characteristics. ${ }^{65}$

\section{Domestic abuse or intimate partner violence}

During a lockdown or similar measures, depending on the socioeconomic factors and population characteristics, there is potential for upward or downward trends in domestic abuse or Intimate partner violence (IPV). The Irish Government launched proactive advertisement campaigns early in the lockdown period to educate and encourage measures against the potential for IPV. IPV is an important public health problem and an association between IPV and PTB has already been demonstrated. Prevalence of IPV was $14.9 \%$ in an Australian study and the main precipitating cause of PTB was antepartum haemorrhage ${ }^{66}$ Psychological abuse by partner was associated with increased risk PTB in one South Indian study. ${ }^{67}$

\section{Cigarette smoke, coffee, alcohol, prescription drugs and street drugs}


medRxiv preprint doi: https://doi.org/10.1101/2020.06.03.20121442; this version posted June 5, 2020. The copyright holder for this preprint (which was not certified by peer review) is the author/funder, who has granted medRxiv a license to display the preprint in perpetuity.

All rights reserved. No reuse allowed without permission.

Approximately $11 \%$ of Irish women smoke during pregnancy and $28 \%$ of those who smoke while pregnant had SGA infants compared to non-smokers at $13 \%{ }^{68}$ Both active and passive (second-hand or environmental) tobacco smoking during pregnancy is associated with risk of SGA and PTB. ${ }^{69,70}$ PTB has been reported for women with drug dependence, cocaine and poly-substance being at the highest risk. $^{71}$

Studies evaluating alcohol consumption during pregnancy are often overshadowed by bias attributable to unmeasured confounders and varying or no impact on PTB rates has been reported. ${ }^{72}$ Meta-analysis showed that high consumption of coffee during pregnancy is associated with low birth weight (LBW) and PTB. ${ }^{73}$ On the other hand certain herbal preparations claim myorelaxant, anti-inflammatory and immunomodulatory properties and were reported as useful in preventing PTB associated with inflammation and infection. ${ }^{11}$

While figures relating to cigarette smoking, alcohol consumption and coffee intake in pregnant women during the Irish lockdown are not yet available, it is hypothesized that with enhanced surveillance by enforcement agencies during this time, the availability, opportunities and the distribution for the illicit drug trade may have been reduced.

\section{Optimising maternal immunizations}

Maternal immunization schedules are increasingly coming under the spotlight as part of the 'life-course' immunization programmes for the role that they play in improving maternal, foetal, and neonatal health. ${ }^{74}$ Even though not primarily targeted to reduce PTB, influenza vaccination during pregnancy indirectly reduces PTB through the reduction of maternal morbidity. ${ }^{74}$ Perhaps the lockdown afforded pregnant women 
medRxiv preprint doi: https://doi.org/10.1101/2020.06.03.20121442; this version posted June 5, 2020. The copyright holder for this preprint (which was not certified by peer review) is the author/funder, who has granted medRxiv a license to display the preprint in perpetuity.

All rights reserved. No reuse allowed without permission.

the opportunity to optimize preventive approaches including immunizations; however ease of access to services apparently was not uniform.

\section{Learning from the lockdown and future strategies to reduce PTB}

Only three VLBW and no ELBW infant admission to the only neonatal intensive care unit (NICU) of one of the health regions of Ireland from $1^{\text {st }}$ January to $30^{\text {th }}$ April of 2020 , resulted in a reduction to zero of morbidity metrics primarily linked to extreme prematurity such as necrotising enterocolitis (NEC), retinopathy of prematurity (ROP) and severe forms (grade 3 and 4) of intraventricular haemorrhage (IVH).

In the absence of significant alterations to antenatal or perinatal hospital-based care pathways, our observed reduction of PTB among the VLBW infants points to the lockdown induced behavioural and socio-environmental modifiers as the catalysts for the reported change. We recommend varied and broadened preventive approaches based on sociodemography, nutrition, lifestyle, and underlying individual genetic and epigenetic variations. ${ }^{75}$ This finding of clinically meaningful reduction of PTB through non-clinical, socially rooted alterations in maternal behaviour and lifestyle along with an enabling environment, challenges the widely held assumption that the agents for prevention of PTB are hospital-based. These observations, if replicated from other regions of the world during the pandemic with varying levels of socio-environmental restrictions triggered by COVID-19, could offer novel perspectives and promising insights facilitating the analysis of yet under-appreciated phenotype of PTB. Statistical modelling approaches and big-data analysis principles would also be critical in this journey to reduce PTB. ${ }^{16}$

Standardized prenatal care and timely perinatal interventions could inherently lead to medically induced PTB, while rendering the desired reduction of foetal and maternal 
medRxiv preprint doi: https://doi.org/10.1101/2020.06.03.20121442; this version posted June 5, 2020. The copyright holder for this preprint (which was not certified by peer review) is the author/funder, who has granted medRxiv a license to display the preprint in perpetuity.

All rights reserved. No reuse allowed without permission.

morbidity and stillbirths. ${ }^{76,77}$ Medicalization of the physiological process of pregnancy is often criticized for excessive monitoring and interventions, most notably in health systems rooted on fee payment at point-of-care, private health insurance or reimbursements. ${ }^{78,79}$ Based on our observations and reflecting on the changing demographics of pregnancy and childbirth, a contextual reconceptualization of antenatal care integrating the domains of health, behaviour, society and environment would appear more effective in reducing the VLBW and ELBW rates.

Our observed new PTB trend, if an outcome of the COVID-19 enforced socioenvironmental and behavioural changes, suggest it is reasonable to postulate, a) the low numbers from early March onwards was influenced by the effects of the prelockdown period of extra public health vigilance that commenced in mid-February, b) effects are immediate, and c) the effects of lockdown will be seen in coming months and sustainable until such time as normality influencers are operating again. However, post-lockdown deterioration in socio-environmental factors or a 'baby boom' in late 2020 could increase the PTB rates.

\section{Limitations, Interpretations and Generalisability}

The following limitations are acknowledged: 1. Inherent reservations posed by retrospective nature of the birth cohort data spanning over two decades; 2. Even though the vast majority of the VLBW infants would be premature, rarely severe intrauterine growth restriction (IUGR) at term could be included. However, such an inclusion consistently over two decades should reduce the bias and the weightbased inclusion criteria would allow comparison to national data by CSO, NPEC and internationally through VON; 3 . Inclusion of January 2020, when there was no official lockdown or enhanced pre-lockdown public health measures. This was 
medRxiv preprint doi: https://doi.org/10.1101/2020.06.03.20121442; this version posted June 5, 2020. The copyright holder for this preprint (which was not certified by peer review) is the author/funder, who has granted medRxiv a license to display the preprint in perpetuity.

All rights reserved. No reuse allowed without permission.

required to make comparison with the two decades of trends including the first four months; 4. Completion of the study prior to the official finish of lockdown was to facilitate ease of comparison against the coded historical monthly data, timely data completion and analysis; 5 . ELBW category could only be analysed with limitations considering the small number of births on a monthly basis; 6 . We caution the "no abortion policy' that Ireland followed till late 2018, when making international comparisons; 7. The lockdown could have deferred what should have been medically offered early during pregnancy as well, thus arguably postponing the gestational age of intervention. Thus it could be viewed that the potential for reduced monitoring opportunities or early foeto-maternal interventions during the lockdown could have 'shifted the band' from VLBW to LBW infants; 9. Our observations are suggestive of potential associations of the socio-environmental and behavioural modifiers with reduced PTB and the study is not designed to evaluate causality. Moreover, our dataset from a regional sample in Ireland is relatively small and thus not strictly reflecting every society's behavioural and socio-environmental response to the COVID-19 lockdown.

\section{Conclusion}

The Irish national lockdown in response to SARS-CoV-2 virus (COVID-19) pandemic and the cumulative effects of socio-environmental variables such as maternal behavioural modifications, opportunities to work-from-home, potential reduction in work related stresses, possible alleviation of physical strain related to work and commuting, optimal opportunities for rest and sleep, likely increase in partner presence and support at home, reduced exposure to infections, improved opportunities for nutritional support and exercise as well as the positive alterations in 
medRxiv preprint doi: https://doi.org/10.1101/2020.06.03.20121442; this version posted June 5, 2020. The copyright holder for this preprint (which was not certified by peer review) is the author/funder, who has granted medRxiv a license to display the preprint in perpetuity.

All rights reserved. No reuse allowed without permission.

environment and air pollution, all would have possibly resulted in a reduction in PTB involving ELBW and VLBW infants. In the context of achieving sustainable development goals (SDG) and to reduce the under-five mortality globally, prematurity rate would be the most important 'curve to bend'. ${ }^{80}$ Further research is needed to enhance our knowledge regarding the complex ways in which environmental, social, behavioural and biological factors interact and modify PTB, an important perinatal event of global significance. We recommend WHO and national policy makers reflect on this positive outcome of the COVID-19 pandemic, the insight that it has provided, and seize the opportunity to recommend further studies from geographically diverse regions to evaluate these implicated interdependent behavioural and socio-environmental modifiers of PTB.

Word count of manuscript: 4637 (limit 5000)

\section{Acknowledgements}

Authors wish to acknowledge Thomas Stack, Gerard Burke, Con Sreenan, Niazy AlAssaf, Margo Dunworth, Deirdre O'Connell, Marie Carroll, Collette Quinn, Irene Byrne, Leona Blackwell and Eamon Leahy for various stages of neonatal and perinatal activity tabulation and verification over the two decades at UMHL. Athanasios Mantas is acknowledged for the information related to the termination of pregnancy (TOP) and Grace McCormack for collating the labour ward activity at UMHL. John Slevin and Rizwan Khan (obstetric and neonatal professionals) as well as Sharon O'Brien (parent of a VLBW infant, as part of PPI) are appreciated for their independent scrutiny and verification of primary VLBW and ELBW data for 2020. Patrick Dillon and Joanne O'Connor are acknowledged for the research governance and ethics approvals. National Perinatal Epidemiology Centre (NPEC) is 
medRxiv preprint doi: https://doi.org/10.1101/2020.06.03.20121442; this version posted June 5, 2020. The copyright holder for this preprint (which was not certified by peer review) is the author/funder, who has granted medRxiv a license to display the preprint in perpetuity.

All rights reserved. No reuse allowed without permission.

acknowledged for the recent Vermont Oxford Network (VON) Ireland information and the Central Statistics Office (CSO) of Ireland for the National data. Obstetric, midwifery, nursing and neonatal professionals of UMHL who otherwise supported the project through their clinical input and assistance are gracefully acknowledged.

\section{Footnotes}

Contributorship statement: RKP conceptualised and designed the study, extracted the ELBW and VLBW data, drafted the initial draft, reviewed and revised the manuscript. ER collected the neonatal activity data and contributed to the nursing and midwifery sections. HP developed the data analysis instruments, conducted the statistical analysis and reviewed and revised the relevant sections. MI contributed to the obstetric data, verified the termination of pregnancy register and reviewed the relevant sections. MD contributed as the patient and public representative, contributed to the relevant sections and developed the search strings. NO cosupervised the research and critically reviewed the infection and microbiology sections. DM co-supervised the research, reviewed and edited the relevant sections. CD coordinated and supervised the research, advised on methodology and manuscript structure and critically reviewed the manuscript for important intellectual content. All authors approved the final manuscript as submitted and agree to be accountable for the work. The corresponding author attests that all listed authors meet authorship criteria and that no others meeting the criteria have been omitted.

Funding: No funding for the study has been received. The views expressed are those of the authors and not necessarily those of employing authorities of authors such as Health Service Executive (HSE), University of Limerick or Irish Neonatal Health Alliance (INHA). 
medRxiv preprint doi: https://doi.org/10.1101/2020.06.03.20121442; this version posted June 5, 2020. The copyright holder for this preprint (which was not certified by peer review) is the author/funder, who has granted medRxiv a license to display the preprint in perpetuity.

All rights reserved. No reuse allowed without permission.

Competing interests: All authors have completed the ICMJE uniform disclosure form at www.icmje.org/coi disclosure.pdf and declare no competing interests.

Ethical approval: Research Ethics Committee of University Hospital Limerick, Ireland, approved the study.

Data sharing: All relevant data included in the manuscript. No additional data available.

The corresponding author affirms that the manuscript is an honest, accurate, and transparent account of the study being reported; that no important aspects of the study have been omitted; and that any discrepancies from the study as planned have been explained.

\section{Dissemination to participants and related patient and public communities:}

There are no individual study participants to disseminate the results to. Neonatal patients advocacy charity (INHA) involved in the study will be sent a copy of the article when published. The authors intend to disseminate the study findings through INHA website and other media so that the results will be available for the wider patient and public communities. 
medRxiv preprint doi: https://doi.org/10.1101/2020.06.03.20121442; this version posted June 5, 2020. The copyright holder for this preprint (which was not certified by peer review) is the author/funder, who has granted medRxiv a license to display the preprint in perpetuity.

\section{References}

1. Liu L, Oza S, Hogan D, Chu Y, Perin J, Zhu J, et al. Global, regional, and national causes of under-5 mortality in 2000-15: an updated systematic analysis with implications for the Sustainable Development Goals. Lancet. 2016;388(10063):3027-35. doi: 10.1016/S0140-6736(16)31593-8.

2. Harrison MS, Goldenberg RL. Global Burden of Prematurity. Semin Fetal Neonatal Med. 2016;21(2):74-9. doi: 10.1016/j.siny.2015.12.007.

3. Purisch SE, Gyamfi-Bannerman C. Epidemiology of Preterm Birth. Semin Perinatol. 2017;41(7):387-391. doi: 10.1053/j.semperi.2017.07.009.

4. Chawanpaiboon S, Vogel JP, Moller AB, Lumbiganon P, Petzold M, Hogan D, Landoulsi S, Jampathong N, Kongwattanakul K, Laopaiboon m, Lewis C, Rattanakanokchai S, Teng DN, Thinkhamrop J, Watananirun K, Zhang J, Zhou W, Gülmezoglu AM. Global, Regional, and National Estimates of Levels of Preterm Birth in 2014: A Systematic Review and Modelling Analysis. Lancet Glob Health. 2019;7(1):e37-e46. doi: 10.1016/S2214-109X(18)30451-0.

5. World Health Organisation (WHO). Take a stand for the right to health. 2018. Accessed $29^{\text {th }} \quad$ April 2020 . http://www.who.int/news-room/factsheets/detail/preterm-birth

6. Bloomfield FH. How is Maternal Nutrition Related to Preterm Birth? Annu Rev Nutr. 2011;31:235-61. doi: 10.1146/annurev-nutr-072610-145141.

7. Goldenberg RL, Culhane JF, lams JD, Romero R. Epidemiology and Causes of Preterm Birth. Lancet. 2008;371(9606):75-84. doi: 10.1016/S01406736(08)60074-4.

8. Beck S, Wojdyla D, Say L, Betran AP, Merialdi M, Requejo JH, Rubens C, Menon R, Van Look PFA. The Worldwide Incidence of Preterm Birth: A 
medRxiv preprint doi: https://doi.org/10.1101/2020.06.03.20121442; this version posted June 5, 2020. The copyright holder for this preprint (which was not certified by peer review) is the author/funder, who has granted medRxiv a license to display the preprint in perpetuity. All rights reserved. No reuse allowed without permission.

Systematic Review of Maternal Mortality and Morbidity. Bull World Health Organ. 2010;88(1):31-8.

9. Wheeler S, Maxson P, Truong T, Swamy G. Psychosocial Stress and Preterm Birth: The Impact of Parity and Race. Matern Child Health j. 2018;22(10):1430-1435. doi: 10.1007/s10995-018-2523-0.

10. Frey HA, Klebanoff MA. The Epidemiology, Etiology, and Costs of Preterm Birth. Semin Fetal Neonatal Med. 2016;21(2):68-73. doi: 10.1016/j.siny.2015.12.011.

11. Muñoz-Pérez VM, Oritz MI, Carino-Cortes R, Fernandez-Martinez E, RochaZavaleta L, Bautista-Avila M. Preterm Birth, Inflammation and Infection: new alternative Strategies for Their Prevention. Curr Pharm Biotechnol. 2019;20(5):354-365. doi: 10.2174/1389201020666190408112013.

12. Linehan LA, Walsh J, Morris A, Kenny L, O’Donoghue K, Dempsey E, Russell N. Neonatal and Maternal outcomes Following Midtrimester Preterm Premature Rupture of the Membranes: A Retrospective Cohort Study. BMC Pregnancy Childbirth. 2016;16:25. doi: 10.1186/s12884-016-0813-3.

13. Cobo T, Kacerovsky M, Jacobson B. Noninvasive Sampling of the Intrauterine Environment in Women with Preterm Labor and Intact Membranes. Fetal Daign Ther. 2018;43(4):241-249. doi: 10.1159/000480232.

14. Gomez-Lopez N, Romero R, Xu Y, Plazyo O, Unkel R, Leng Y, Than NG, Chaiworapongsa T, Panaitescu B, Dong Z, Tarca AL, Abrahams VM, Yeo L, Hassan SS. Reprod Sci. 2017;24(10):1382-1401. doi: 10.1177/1933719116687656. 
medRxiv preprint doi: https://doi.org/10.1101/2020.06.03.20121442; this version posted June 5, 2020. The copyright holder for this preprint (which was not certified by peer review) is the author/funder, who has granted medRxiv a license to display the preprint in perpetuity. All rights reserved. No reuse allowed without permission.

15.Laudanski P, Lemancewicz A, Kuc P, Charkiewicz K, Ramotowska B, Kretowska M, Jasinska E, Raba G, Karwasik-Kajszczarek K, Kraczkowski J, Laundanski T. Chemokines profiling of patients with preterm birth. Mediators Inflamm. 2014;2014:185758. doi: 10.1155/2014/185758.

16. Govindaswami B, Jagatheesan P, Nudelman M, Narasimhan SR. Prevention of Prematurity: Advances and Opportunities. Clin Perinatol. 2018;45(3): 579595. doi: 10.1016/j.clp.2018.05.013.

17. Delnord M, Blondel B, Zeitlin J. What Contributes to Disparities in the Preterm Birth Rate in European Countries? Curr Opin Obstet Gynecol. 2015;27(2):133-42. doi: 10.1097/GCO.0000000000000156.

18. History of Abortion in Ireland. Irish Family Planning Association (IFPA). https://www.ifpa.ie/advocacy/abortion-in-ireland-legal-timeline/ Accessed $5^{\text {th }}$ May 2020.

19. Census 2016. Central Statistics Office (CSO). https://www.cso.ie/en/census/ Accessed $5^{\text {th }}$ May 2020.

20. Philip RK, Ismail A, Murphy B, Mirza A, Quinn C, Dunworth M. Caffeine Treatment for Apnea of Prematurity and the Influence on Dose-Dependent Postnatal Weight Gain Observed Over 15 years. J Caffeine Adenosine Res. 018;8(3):99-106. doi: 10.1089/caff.2018.0005.

21. Vermont Oxford Network. https://public.vtoxford.org Accessed on $09^{\text {th }}$ May 2020.

22. Central Statistics Office (CSO) Ireland. www.cso.ie/en/releasesandpublications/ep/pvsys/vitalstatisticsyearlysummary2018/ Accessed on 24 ${ }^{\text {th }}$ April 2020. 
medRxiv preprint doi: https://doi.org/10.1101/2020.06.03.20121442; this version posted June 5, 2020. The copyright holder for this preprint (which was not certified by peer review) is the author/funder, who has granted medRxiv a license to display the preprint in perpetuity.

23. Leitao S, Twomey A, Murphy BP, Corcoran P, Drummond L, Greene RA, on behalf of NICORE Republic of Ireland. Very Low Birth Weight Infants in the Republic of Ireland annual report 2017. National Perinatal Epidemiology centre, 2019. www.ucc.ie/en/npec/ Accessed on 25 ${ }^{\text {th }}$ April 2020.

24. Philip RK. General Data Protection Regulation (GDPR) and Paediatric Medical Practice in Ireland: a Personal reflection. Ir $\mathrm{J}$ Med Sci. 2019;188(2):721-724. doi: 10.1007/s11845-018-1857-3.

25. Daly M. Parental Perspective on Neonatal Outcomes. BMJ Paediatr Open. 2019;3(1):e000404. doi: 10.1136/bmjpo-2018-000404.

26. Sun Z, Yang L, Bai X, Du W, Shen G, Fej J, Wang Y, Chen A, Chen Y, Zhao M. Maternal Ambient Air Pollution Exposure With Spatial-Temporal Variations and Preterm Birth Risk Assessment During 2013-2017 in Zhejiang Province, China. Environ Int. 2019;133(Pt b):105242. doi: 10.1016/j.envint.2019.105242.

27. Zeitlin J, Szamotulska K, Drewniak N, Mohangoo AD, Chalmers J, Sakkeus L, Irgens L, Gatt M, Gissler M, Blondel B, Euro-Peristat Preterm Study Group. Preterm Birth Time Trends in Europe: A Study of 19 Countries. BJOG. 2013;120(11):1356-65. doi: 10.1111/1471-0528.12281.

28. Murphy M, McHugh S, O’Keeffe LM, Greene RA, Corcoran P, Kearney PM. Preventive health counselling during antenatal care using the pregnancy risk assessment monitoring system (PRAMS) in Ireland. BMC Preg Childbirth. 2020;20(1):98. doi: 10.1186/s12884-020-2756-y.

29. Care A, Ingleby L, Alfirevic Z, Sharp A. The Influence of the Introduction of National Guidelines on Preterm Birth Prevention Practice: UK Experience. BJOG. 2019;126(6):763-769. doi: 10.1111/1471-0528.15549. 
medRxiv preprint doi: https://doi.org/10.1101/2020.06.03.20121442; this version posted June 5, 2020. The copyright holder for this preprint (which was not certified by peer review) is the author/funder, who has granted medRxiv a license to display the preprint in perpetuity. All rights reserved. No reuse allowed without permission.

30. Story L, Simpson NAB, David AL, Alfirevic Z, Bennett PR, Jolly M, Shennan AH, UK Preterm Clinical Network. Reducing the Impact of Preterm Birth: Preterm Birth Commissioning in the United Kingdom. Eur J obstet Gynecol Reprod Biol. 2019;3:100018. doi: 10.1016/j.eurox.2019.100018.

31. Ludwig L. Prenatal Period of Life as a Matrix for Our Lives and Our Societies. J Psychohist. 2012;39(4):291-305.

32. Gluckman PD, Hanson MA. Living with the past: evolution, development, and patterns of disease. Science. 2004;305:1733-1736. doi:10.1126/science.1095292.

33. Williams TC, Drake AJ. Preterm birth in evolutionary context: a predictive adaptive model. Philosophical Transactions B. 2019;374:20180121. doi:10.1098/rstb.2018.0121.

34. Lederman RP. Preterm birth prevention: a mandate for psychosocial assessment. Issues Ment Health Nurs. 2011;32(3):163-9. doi: $10.3109 / 01612840.2010 .538812$

35. Giurgescu C, Templin TN. Father Involvement and Psychological Well-Being of Pregnant Women. Am J Matern Child Nurs. 2015;40(6):381-7. doi: 10.1097/NMC.0000000000000183.

36. Staneva A, Bogossian F, Pritchard M, Wittkowski A. The effects of maternal depression, anxiety and perceived stress during pregnancy on preterm birth: A systematic review. Women Birth. 201528(30;179-93. doi: 10.1016/j.wombi.2015.02.003.

37. Hall JS, Ferguson SA, Turner AI, Robertson SJ, Vincent GE, Aisbett B. The effect of Working On-Call on Stress Physiology and Sleep: A Systematic Review. Sleep Med Rev. 2017;33:79-87. doi: 10.1016/j.smrv.2016.06.001. 
medRxiv preprint doi: https://doi.org/10.1101/2020.06.03.20121442; this version posted June 5, 2020. The copyright holder for this preprint (which was not certified by peer review) is the author/funder, who has granted medRxiv a license to display the preprint in perpetuity. All rights reserved. No reuse allowed without permission.

38. Bandoli G, Jelliffe-Pawlowski L, Feuer SK, Liang L, Oltman SP, Paynter R, Ross KM, Schetter CD, Ryckman KK, Chambers CD. Second Trimester Serum Cortisol and Preterm Birth: An Analysis by Timing and Subtype. J Perinatol. 2018;38(8):973-981. doi: 10.1038/s41372-018-0128-5.

39. Kramer MS, Lydon J, Seguin L, Goulet L, Kahn SR, McNamanara H, Genest J, Dessa C, Chen MF, Sharma S, Meaney MJ, Thomson S, Uum SV, Koren G, Dahhou M, Lamoureux J, Platt RW. Stress Pathways to Spontaneous Preterm Birth: The Role of Stressors, Psychological Distress, and Stress Hormones. Am J Epidemiol. 2009;1:169(11):1319-26. doi: 10.1093/aje/kwp061.

40. Cai C, Vandermeer B, Khurana R, Nerenberg K, Featherstone R, Sebastianski M, Davenport MH. The Impact of Occupational Shift Work and Working Hours During Pregnancy on Health Outcomes: A Systematic Review and Meta-Analysis. Am J Obstet Gynecol. 2019;221(6):563-576. doi: 10.1016/j.ajog.2019.06.051.

41. Pompeii LA, Savitz DA, Evenson KR, Rogers B, McMahon M. Physical Exertion at work and the Risk of Preterm delivery and Small-For-GestationalAge Birth. Obstet Gynecol. 2005;106(6):1279-88. doi: 10.1097/01.AOG.0000189080.76998.f8.

42. Zhu JL, Hiollund NH, Oslen J, National Birth Cohort in Denmark. Shift Work, Duration of Pregnancy, and Birth weight: The national Birth Cohort in Denmark. Am J Obstet Gynecol. 2004;191(1):285-91. doi: 10.1016/j.ajog.2003.12.002. 
medRxiv preprint doi: https://doi.org/10.1101/2020.06.03.20121442; this version posted June 5, 2020. The copyright holder for this preprint (which was not certified by peer review) is the author/funder, who has granted medRxiv a license to display the preprint in perpetuity. All rights reserved. No reuse allowed without permission.

43. Escriba-Aguir V, Perez-Hoyos S, Saurel-Cubizolles MJ. Physical Load and Physiological Demand at Work During Pregnancy and Preterm Birth. Int Arch Occup Environ Health. 2001;74(8):583-8. doi: 10.1007/s004200100259.

44. Bonzini M, Coggon D, Godfrey K, Inskip H, Crozier S, Palmer KT. Occupational Physical Activities, working Hours and Outcome of Pregnancy: Findings From the Southampton Women's Survey. Occup Environ Med. 2009;66(10):685-90. doi: 10.1136/oem.2008.043935.

45. Sosa CG, Althabe F, Belizan JM, Bergel E. Bed Rest in Singleton Pregnancies for Preventing Preterm Birth. Cochrane Database Syst Rev. 2015;2015(3):CD003581. doi: 10.1002/14651858.CD003581.pub3.

46. Byrnes J, Mahoney R, Quaintance C, Gould JB, Carmichael S, Shaw GM, Showen A, Phibbs C, Stevenson DK, Wise PH. Spatial and Temporal Patterns in Preterm Birth in the United States. Pediatr Res. 2015;77(6):83644. doi: 10.1038/pr.2015.55.

47. Klepac P, Locatelli I, Korosec S, Kunzli N, Kukec A. Ambient Air Pollution and Pregnancy Outcomes: A Comprehensive Review and Identification of Environmental Public Health Challenges. Environ Res.2018;167:144-159. doi: 10.1016/j.envres.2018.07.008.

48.Song J, Lu M, An Z, Liu Y, Zheng L, Li Y, Chao L, Xu D, Yao S, Wu W. Estimating the Acute Effects of Ambient Ozone Pollution on the Premature Rupture of Membranes in Xinxiang, China. Chemosphere. 2019;227:191-197. 49. Hu J, Xia W, Pan X, Zheng T, Zhang B, Zhou A, Buka SL, Bassig BA, Liu W, Wu C, Peng Y, Li J, Zhang C, Liu H, Jiang M, Wang Y, Zhang J Huang Z, Zheng D, Shi K, Qian Z, Li Y, Xu S. Association of Adverse Birth Outcomes With Prenatal Exposure to Vanadium: A Population-Based Cohort Study. 
medRxiv preprint doi: https://doi.org/10.1101/2020.06.03.20121442; this version posted June 5, 2020. The copyright holder for this preprint (which was not certified by peer review) is the author/funder, who has granted medRxiv a license to display the preprint in perpetuity. All rights reserved. No reuse allowed without permission.

Lancet Planet Health. 2017;1(6):e230-e241. doi: 10.1016/S25425196(17)30094-3.

50. Lam DA, Miron JA. Temperature and Seasonality of Births. Adv Exp Med Biol. 1991;286:73-88. doi: 10.1007/978-1-4684-5913-5_7.

51. Coronavirus lockdown sees air pollution plummet across UK. BBC News $8^{\text {th }}$ April 2020. https://www.bbc.com/news/uk-england-52202974. Accessed $15^{\text {th }}$ May 2020.

52. Madden D. The Relationship Between Low Birth Weight and Socioeconomic Status in Ireland. J Biosoc Sci. 2014;46(2):248-65. doi: 10.1017/S0021932013000187.

53. Stacey T, Prady S, Haith-Cooper M, Downe S, Simpson N, Pickett K. EthnoSpecific Risk Factors for Adverse Pregnancy Outcomes: Findings From the Born in Bradford Cohort Study. Matern Child Health J. 2016;20(7):1394-404. doi: 10.1007/s10995-016-1936-x.

54. Huang L, Fan L, Ding P, He Y, Xie C, Niu Z, Tian F, Yuan S, Jia D, Chen W. Maternal Exercise During Pregnancy Reduces the Risk of Preterm Birth Through the Mediating Role of Placenta. J Matern Fetal Neonatal Med. 2019;32(1):109-116. doi: 10.1080/14767058.2017.1372415.

55. Healthy Ireland. \#In This Together National Initiatives. https://www.gov.ie/en/publication/221ed8-inthistogether-national-initiatives/ Accessed $15^{\text {th }}$ May 2020

56. Beigi R. Emerging Infectious Diseases in Pregnancy. Obstet Gynecol. 2017;129(5):896-906. doi: 10.1097/AOG.0000000000001978.

57. Henriksen RE, Torsheim T, Thuen F. Relationship Satisfaction Reduces the Risk of Maternal Infectious Diseases in Pregnancy: The Norwegian Mother 
medRxiv preprint doi: https://doi.org/10.1101/2020.06.03.20121442; this version posted June 5, 2020. The copyright holder for this preprint (which was not certified by peer review) is the author/funder, who has granted medRxiv a license to display the preprint in perpetuity. All rights reserved. No reuse allowed without permission.

and Child Cohort Study. PLoS One. 2015;10(1):e0116796. doi: 10.1371/journal.pone.0116796.

58. Pass RF, Little EA, Stagno S, Britt WJ, Alford CA. Young Children as a Probable Source of Maternal and Congenital Cytomegalovirus Infection. N Eng J Med. 1987;316(22):1366-70. doi: 10.1056/NEJM198705283162203.

59. Meijer WJ, van Noortwijk AGA, Bruinse HW, Wensing AMJ. Influenza Virus Infection in Pregnancy: A Review. Acta Obstet Gynecol Scand. 2015;94(8):797-819. doi: 10.1111/aogs.12680.

60. Crane J, Mundle W, Boucoiran I, Maternal Fetal Medicine Committee. Parvovirus B19 Infection in Pregnancy. J Obstet Gynaecol Can. 2014;36(12):1107-1116. doi: 10.1016/S1701-2163(15)30390-X.

61. Lazzarotto T, Lanari M. Why Is Cytomegalovirus the Most Frequent Cause of Congenital Infection? Expert Rev Anti Infect Ther. 2011;9(10):841-3. doi: 10.1586/eri.11.109.

62. Vladutiu CJ, Marshall SW, Poole C, Casteel C, Menard MK, Weiss HB. Adverse Pregnancy Outcomes Following Motor Vehicle Crashes. Am J Prev Med. 2013;45(5):629-36. doi: 10.1016/j.amepre.2013.06.018.

63. Aitokallio-Tallberg A, Halmesmäki. Motor Vehicle Accident During the Second or Third Trimester of Pregnancy. Acta Obstet Gynecol Scand. 1997;76(4):313-7. doi: 10.1111/j.1600-0412.1997.tb07984.x.

64. Auriault F, Thollon L, Pérès J, Behr M. Adverse fetal Outcome in Road Accidents: injury Mechanism Study and Injury Criteria Development in a Pregnant Woman Finite Element Model. Accid Anal Prev. 2016;97:96-102. doi: 10.1016/j.aap.2016.08.026. 
medRxiv preprint doi: https://doi.org/10.1101/2020.06.03.20121442; this version posted June 5, 2020. The copyright holder for this preprint (which was not certified by peer review) is the author/funder, who has granted medRxiv a license to display the preprint in perpetuity. All rights reserved. No reuse allowed without permission.

65. Chibber R, Al-Sibai MH, Qahtani N. Adverse Outcome of Pregnancy Following Air Travel: A Myth or a Concern? Aust NZ Obstet Gynaecol. 2006;46(1):24-8. doi: 10.1111/j.1479-828X.2006.00508.x.

66. Watson LF, Taft AJ. Intimate Partner Violence and the Association With very Preterm Birth. Birth. 2013;40(1):17-23. doi: 10.1111/birt.12024.

67. Rao D, Kumar S, Mohanraj R, Frey S, Manhart L, Kaysen DL. The Impact of Domestic Violence and Depressive Symptoms on Preterm Birth in South India. Soc Psychiatry Psychiatr Epidemiol. 2016;51(2):225-32. doi: 10.1007/s00127-015-1167-2.

68. McDonnell BP, Keogan S, Clancy L, Regan C. Smoking Cessation Support and Obstetric Outcomes in an Irish Maternity Hospital. Eur J Obstet Gynecol Reprod Biol. 2019;232:1-4. doi: 10.1016/j.ejogrb.2018.11.005.

69. Miyake Y, Tanaka K, Arakawa M. Active and passive maternal Smoking During Pregnancy and Birth Outcomes: The Kyushu Okinawa Maternal and Child Health Study. BMC Pregnancy Childbirth.2013;13:157. doi: 10.1186/1471-2393-13-157.

70. Cui H, Gong TT, Liu CX, Wu OJ. Association Between Passive Maternal Smoking During Pregnancy and Preterm birth: Evidence From a MetaAnalysis of Observational Studies. PLoS One. 2016;11(1);e0147848. doi: 10.1371/journal.pone.0147848.

71. Baer JR, Chambers CD, Ryckman K, Oltman SP, Rand L, Jelliffe-Pawlowski LL. Risk of Preterm and Early Term Birth by Maternal Drug Use. J Perinatol. 2019;39(2):286-294. doi: 10.1038/s41372-018-0299-0.

72. Strandberg-Larsen K, Poulsen G, Bech BH, Chatzi L, Codier S, Dale MTG, Fernandez M, Henriksen TB, Jaddoe VW, Kogevinas M, Kruithof CJ, Lindhard 
medRxiv preprint doi: https://doi.org/10.1101/2020.06.03.20121442; this version posted June 5, 2020. The copyright holder for this preprint (which was not certified by peer review) is the author/funder, who has granted medRxiv a license to display the preprint in perpetuity. All rights reserved. No reuse allowed without permission.

MS, Magnus P, Nohr EA, Richiardi L, Rodriguez-Bernal CL, Rouget F, Rusconi F, Vrijheid M, Andersen AN. Association of Light-To-Moderate Alcohol Drinking in Pregnancy With Preterm Birth and Birth Weight: Elucidating Bias by Pooling Data From Nine European Cohorts. Eur $\mathrm{J}$ epidemiol. 2017;32(9):751-764. Doi: 10.1007/s10654-017-0323-2.

73. Poole R, Kennedy OJ, Roderick P, Fallowfield JA, Hayes PC, Parkes J. Coffee Consumption and Health: Umbrella Review of Meta-Analysis of Multiple Health Outcomes. BMJ. 2017;359:j5024. doi: 10.1136/bmj.j5024.

74. Bergin N, Murtagh J, Philip RK. Maternal Vaccination as an Essential Component of Life-course Immunization and Its Contribution to Preventive Neonatology. Int J Environ Res Public Health. 2018;15(5):847. doi: 10.3390/ijerph15050847

75. Daly M. Parental Perspective on Neonatal Outcomes. BMJ Paediatr Open. 2019;3(1):e000404. doi: 10.1136/bmjpo-2018-000404.

76. Medley N, Vogel JP, Care A, Alfirevic Z. Interventions During Pregnancy to Prevent Preterm Birth: an Overview of Cochrane Systematic Reviews. Cochrane database Syst Rev. 2018;11(11):CD012505. doi: 10.1002/14651858.CD012505.pub2.

77. Farrant BM, White SW, Shepherd CCJ. Trends and Predictors of Extreme Preterm Birth: Western Australian Population-Based Cohort Study. PLoS One. 2019;14(3):e0214445. doi: 10.1371/journal.pone.0214445.

78. Johanson R, Newburn M, Macfarlane A. Has the medicalisation of childbirth gone too far? BMJ. 2002;324(7342):892-5. doi: 10.1136/bmj.324.7342.892.BMJ. 2002. 
medRxiv preprint doi: https://doi.org/10.1101/2020.06.03.20121442; this version posted June 5, 2020. The copyright holder for this preprint (which was not certified by peer review) is the author/funder, who has granted medRxiv a license to display the preprint in perpetuity.

All rights reserved. No reuse allowed without permission.

79. Kundisova L, Nante N, Cuccaro C, Mariottini E, Alaimo L. Does the overmedicalisation of pregnancy help to improve neonatal outcomes? Eur J Pub Health. 2019;29(4S):344-345 doi:10.1093/eurpub/ckz187.127

80. World Health Organisation. Health in 2015: from MDGs to SDGs. 2015. http://apps.who.int/iris/bitstream/10665/200009/1/9789241565110_eng.pdf?u $\mathrm{a}=1$ Accessed $31^{\text {st }}$ May 2020 . 
medRxiv preprint doi: https://doi.org/10.1101/2020.06.03.20121442; this version posted June 5, 2020. The copyright holder for this preprint (which was not certified by peer review) is the author/funder, who has granted medRxiv a license to display the preprint in perpetuity.

All rights reserved. No reuse allowed without permission.

\begin{tabular}{|r|r|rr|rr|r|rr|rr|}
\hline \multicolumn{2}{|c|}{} & \multicolumn{2}{|c|}{ January - April } & \multicolumn{4}{|c|}{ Annual } \\
\hline & & \multicolumn{2}{|c|}{ ELBW } & \multicolumn{2}{|c|}{ VLBW } & & \multicolumn{2}{|c|}{ ELBW } & \multicolumn{2}{|c|}{ VLBW } \\
Year & Live & Cou & Rate/10 & Cou & Rate/10 & Live & Cou & Rate/10 & Cou & Rate/10 \\
& Births & nt & $\mathbf{0 0}$ & nt & $\mathbf{0 0}$ & Births & nt & $\mathbf{0 0}$ & nt & $\mathbf{0 0}$ \\
\hline $\mathbf{2 0 0 1}$ & 1337 & 4 & 2.99 & 12 & 8.98 & 4042 & 15 & 3.71 & 32 & 7.92 \\
$\mathbf{2 0 0 2}$ & 1428 & 2 & 1.40 & 15 & 10.50 & 4371 & 6 & 1.37 & 31 & 7.09 \\
$\mathbf{2 0 0 3}$ & 1498 & 5 & 3.34 & 13 & 8.68 & 4514 & 16 & 3.54 & 42 & 9.30 \\
$\mathbf{2 0 0 4}$ & 1458 & 7 & 4.80 & 12 & 8.23 & 4418 & 20 & 4.53 & 37 & 8.37 \\
$\mathbf{2 0 0 5}$ & 1447 & 3 & 2.07 & 13 & 8.98 & 4411 & 10 & 2.27 & 41 & 9.29 \\
$\mathbf{2 0 0 6}$ & 1539 & 4 & 2.60 & 12 & 7.80 & 4692 & 16 & 3.41 & 47 & 10.02 \\
$\mathbf{2 0 0 7}$ & 1704 & 6 & 3.52 & 18 & 10.56 & 5153 & 12 & 2.33 & 55 & 10.67 \\
$\mathbf{2 0 0 8}$ & 1818 & 4 & 2.20 & 12 & 6.60 & 5443 & 12 & 2.20 & 38 & 6.98 \\
$\mathbf{2 0 0 9}$ & 1803 & 6 & 3.33 & 17 & 9.43 & 5432 & 13 & 2.39 & 44 & 8.10 \\
$\mathbf{2 0 1 0}$ & 1676 & 6 & 3.58 & 14 & 8.35 & 5233 & 17 & 3.25 & 52 & 9.94 \\
$\mathbf{2 0 1 1}$ & 1671 & 4 & 2.39 & 10 & 5.98 & 5137 & 11 & 2.14 & 27 & 5.26 \\
$\mathbf{2 0 1 2}$ & 1655 & 6 & 3.63 & 12 & 7.25 & 4905 & 17 & 3.47 & 43 & 8.77 \\
$\mathbf{2 0 1 3}$ & 1580 & 2 & 1.27 & 11 & 6.96 & 4594 & 13 & 2.83 & 42 & 9.14 \\
$\mathbf{2 0 1 4}$ & 1482 & 3 & 2.02 & 10 & 6.75 & 4522 & 13 & 2.87 & 36 & 7.96 \\
$\mathbf{2 0 1 5}$ & 1565 & 4 & 2.56 & 10 & 6.39 & 4690 & 12 & 2.56 & 45 & 9.59 \\
$\mathbf{2 0 1 6}$ & 1483 & 4 & 2.70 & 14 & 9.44 & 4473 & 10 & 2.24 & 34 & 7.60 \\
$\mathbf{2 0 1 7}$ & 1406 & 7 & 4.98 & 14 & 9.96 & 4416 & 16 & 3.62 & 35 & 7.93 \\
$\mathbf{2 0 1 8}$ & 1464 & 3 & 2.05 & 9 & 6.15 & 4439 & 11 & 2.48 & 37 & 8.34 \\
$\mathbf{2 0 1 9}$ & 1310 & 8 & 6.11 & 12 & 9.16 & 4144 & 15 & 3.62 & 31 & 7.48 \\
$\mathbf{2 0 2 0}$ & 1381 & 0 & 0.00 & 3 & 2.17 & & & & & \\
\hline
\end{tabular}

Table 1: University Maternity Hospital Limerick (UMHL) Regional data of VLBW and ELBW births for 2001-2020. 
medRxiv preprint doi: https://doi.org/10.1101/2020.06.03.20121442; this version posted June 5, 2020. The copyright holder for this preprint (which was not certified by peer review) is the author/funder, who has granted medRxiv a license to display the preprint in perpetuity.

All rights reserved. No reuse allowed without permission.

\begin{tabular}{|r|r|rr|rr|rr|rr|}
\hline \multicolumn{2}{|c|}{} & \multicolumn{4}{|c|}{ CSO National Data } & \multicolumn{3}{c|}{ VON National Data } \\
\hline \multirow{2}{*}{ Year } & & \multicolumn{2}{|c|}{ ELBW } & \multicolumn{2}{c|}{ VLBW } & \multicolumn{2}{c|}{ ELBW } & \multicolumn{2}{c|}{ VLBW } \\
& Live & Coun & Rate/100 & Coun & Rate/100 & Coun & Rate/100 & Coun & Rate/100 \\
& Births & $\mathbf{t}$ & $\mathbf{0}$ & $\mathbf{t}$ & $\mathbf{0}$ & $\mathbf{t}$ & $\mathbf{0}$ & $\mathbf{t}$ & $\mathbf{0}$ \\
\hline $\mathbf{2 0 1 1}$ & 74033 & 226 & 3.05 & 599 & 8.09 & & & & \\
$\mathbf{2 0 1 2}$ & 71674 & 259 & 3.61 & 653 & 9.11 & & & & \\
$\mathbf{2 0 1 3}$ & 68954 & 265 & 3.84 & 653 & 9.47 & & & & \\
$\mathbf{2 0 1 4}$ & 67295 & 218 & 3.24 & 576 & 8.56 & 226 & 3.36 & 596 & 8.86 \\
$\mathbf{2 0 1 5}$ & 65536 & 214 & 3.27 & 585 & 8.93 & 221 & 3.37 & 622 & 9.49 \\
$\mathbf{2 0 1 6}$ & 63841 & 247 & 3.87 & 584 & 9.15 & 250 & 3.92 & 593 & 9.29 \\
$\mathbf{2 0 1 7}$ & 61824 & 222 & 3.59 & 575 & 9.30 & 238 & 3.85 & 612 & 9.90 \\
\hline
\end{tabular}

Table 2: National Irish data for VLBW and ELBW births based on the published CSO and VON numbers. CSO- Central statistics office. VON- Vermont Oxford Network.

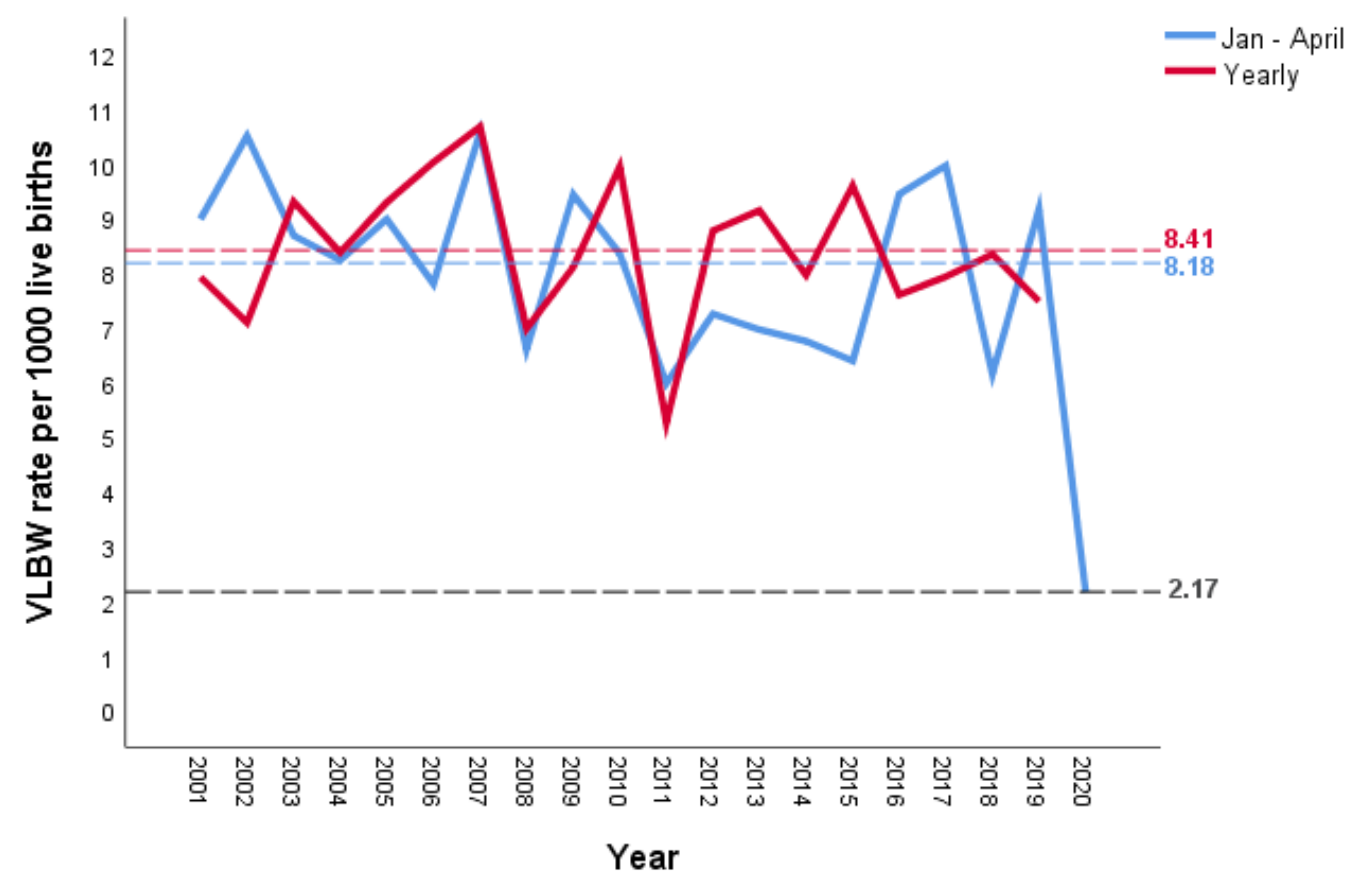

Figure 1: VLBW births from January - April and Yearly for UMHL from 2001-2020. 
medRxiv preprint doi: https://doi.org/10.1101/2020.06.03.20121442; this version posted June 5, 2020. The copyright holder for this preprint (which was not certified by peer review) is the author/funder, who has granted medRxiv a license to display the preprint in perpetuity.

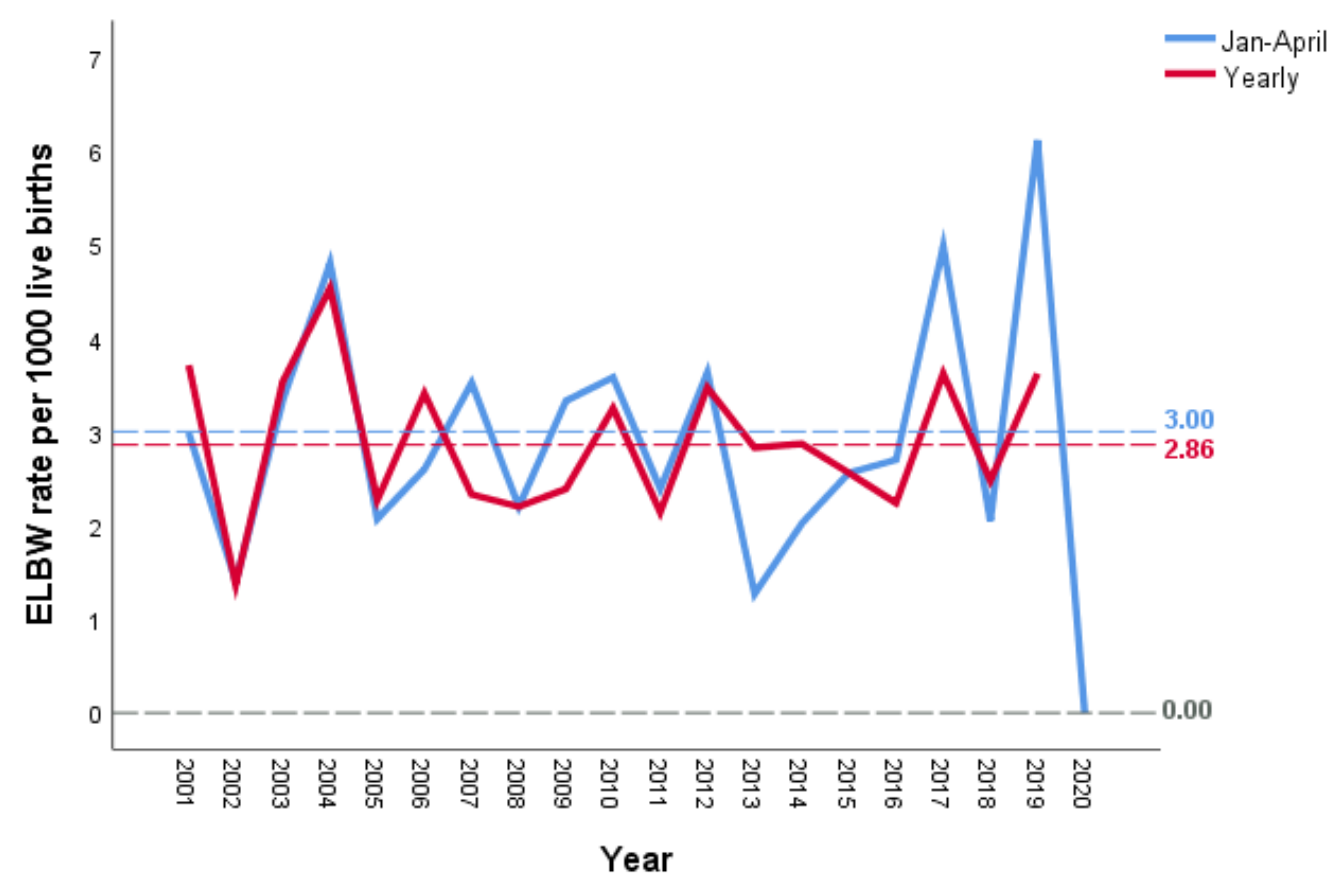

Figure 2: ELBW births from January - April and Yearly for UMHL from 2001-2020.

Figure: 3 COVID-19 lockdown in Ireland and reduction of preterm birth of VLBW infants: potential contributors.

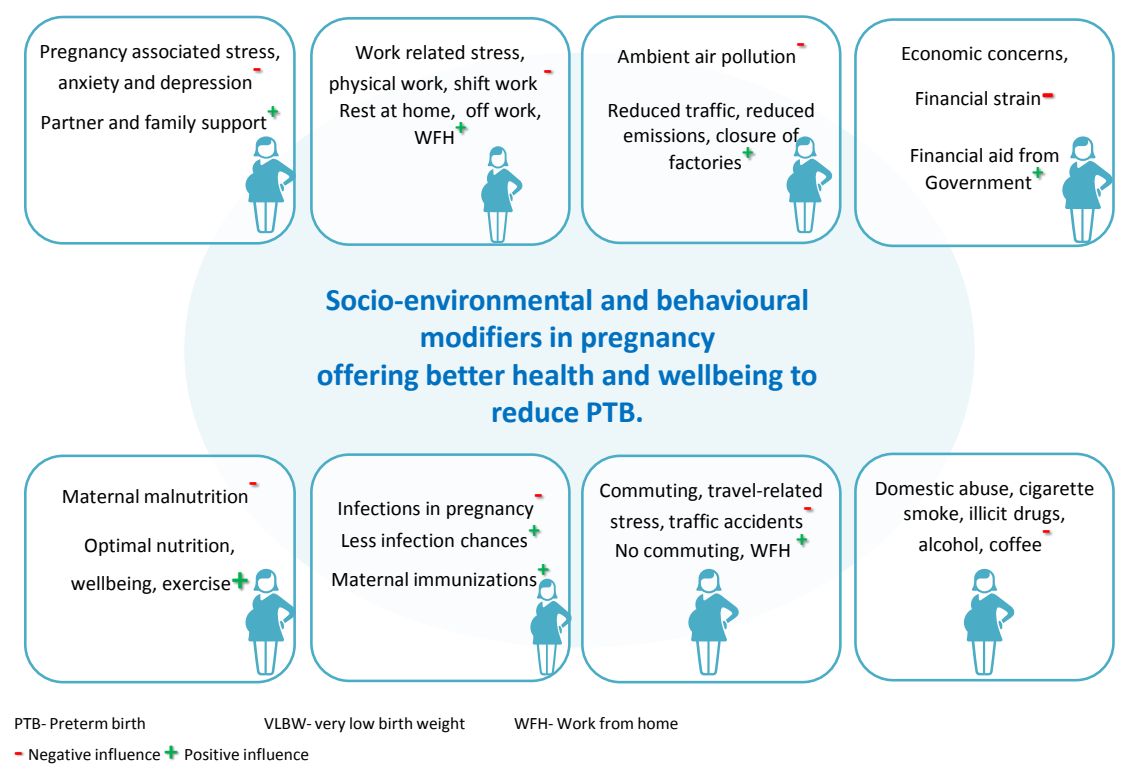

Figure 3: How the COVID-19 lockdown in Ireland possibly contributed to the reduction of preterm birth of VLBW infants. 
medRxiv preprint doi: https://doi.org/10.1101/2020.06.03.20121442; this version posted June 5, 2020. The copyright holder for this preprint (which was not certified by peer review) is the author/funder, who has granted medRxiv a license to display the preprint in perpetuity.

All rights reserved. No reuse allowed without permission.

\begin{tabular}{rccccc}
\hline Time Period & Births & VLBW & Rate (Wald 95\% CI) & Rate Ratio (95\% CI) & p-value \\
\hline $\mathbf{2 0 0 1 - 2 0 1 9}$ & 29324 & 240 & $8.18(7.21,9.29)$ & $3.77(1.21,11.75)$ & 0.022 \\
$\mathbf{2 0 2 0}$ & 1381 & 3 & $2.17(0.70,6.74)$ & & \\
\hline
\end{tabular}

Supplementary Table 1: Poisson Regression Analysis of VLBW counts Jan - April at UMHL

\begin{tabular}{lcccccc}
\hline & Time Period & Births & VLBW & Rate (Wald 95\% CI) & ELBW & Rate (Wald 95\% Cl) \\
\hline UMHL & $2001-2019$ & 89029 & 749 & $8.41(7.83,9.04)$ & 255 & $2.86(2.53,3.24)$ \\
National CSO & $2011-2017$ & 473157 & 4225 & $8.93(8.66,9.20)$ & 1615 & $3.41(3.25,3.58)$ \\
National VON & $2014-2017$ & 258496 & 2343 & $9.37(9.01,9.75)$ & 935 & $3.62(3.39,3.86)$ \\
\hline
\end{tabular}

Supplementary Table 2: Annual VLBW and ELBW counts and rates per 1000 live births at UMHL and nationally. 